\title{
Pepino Dulce ( Solanum muricatum Ait.) Quality Characteristics Respond to Nitrogen Nutrition and Salinity
}

\author{
D. Pluda, ${ }^{1}$ H.D. Rabinowitch, and U. Kafkafi \\ Faculty of Agriculture, The Hebrew University of Jerusalem, Rehovot, 76100, Israel
}

Additional index words. ascorbate, genotypes, fertility, salt tolerance, vegetable production, flavor

\begin{abstract}
The effect of fertigation with $\mathrm{N}-\mathrm{NO}_{3}$ at 3, 6, or $12 \mathrm{mmol} \cdot \mathrm{liter}^{-1}$, and 0 , 3, or $6 \mathrm{dS} \cdot \mathrm{m}^{-1} \mathrm{chloride}$ ions on fruit quality of three pepino dulce selections was studied. Genotypes varied considerably in their response to mineral treatments in most quality characteristics. Variation in fruit size was greatly reduced when clusters were thinned to three fruit. Increasing chloride concentration in the nutrient soltuion reduced fruit size significantly and ascorbic acid concentration relative to the control, but fruit shape was not affected. Increases in $\mathrm{NaCl}$ salt, but not $\mathrm{N}$ concentration, resulted in significantly higher soluble solids concentration (SSC) and firmness in all three genotypes. Electrical conductivity, acidity, and $\mathrm{pH}$ were significantly affected by the two mineral treatments in the first trial, but remained unchanged in the second season. Fruit firmness, SSC, and acidity declined by $12 \%$ to $30 \%$, whereas ascorbic acid content increased during 14 days storage at room temperature. These changes depended on genotype and environment during fruit growth and development. Organoleptic ratings were highest in salt-treated plants. Fruit quality of pepino dulce may be manipulated by crop management, thus improving its acceptability in Western markets.
\end{abstract}

Pepino dulce is endemic in many South American countries (Heiser, 1964, 1969). The day neutral herbaceous plants bear clusters of purplish to white flowers on trailing stems that branch and root easily. Hence, selected plants are clonally propagated by growers. The number of seeds per fruit in seed forming plants varies between < 10 and 200 (Anderson, 1979), but many cultivars in Ecuador (Heiser, 1964; Hermann, 1988; Popenoe, 1924) develop parthenocarpic fruit (Hermann, 1988). Ripening of pepino dulce fruit is characterized by a climacteric (El Zeftawi et al., 1988; Lizana and Levano, 1977). Ripening fruit are aromatic (Shiota et al., 1988), tender, and juicy but vary greatly in shape, color, size (Hermann, 1988), and also in sugar (Cossio, 1986; Dennis et al., 1981; Kameraz, 1958) SSC (El Zeftawi et al., 1988; Endt, 1983; Hermann, 1988; Rilska and Borenstein, 1987), and $\mathrm{pH}$ (Levano Herrera, 1977). They are high in vitamin C (Hermann, 1988; Morley-Bunker, 1983; Redgewell and Turner, 1986; Yamaguchi, 1978) and vary greatly in flavor (Dennis et al., 1981; Heiser, 1964; 1969; Hermann, 1988), in many cases leaving an off-flavor sensation.

Salinity stress inhibits growth and development (Bernstein, 1964; Maas and Nieman, 1977; Pasternak et al., 1979), causing osmotic stress (Maas and Nieman, 1977) and yield loses (Mass and Nieman, 1977) and can be toxic to plants (Levitt, 1980). In addition, $\mathrm{Na}$ and chloride ions may inhibit absorption of essential minerals (Levitt, 1980). The effect of osmotic stress on flavor of pepino dulce fruit has not been investigated. However, melon ( Cucumis melo L.) (Levitt, 1980) and tomato ( Lycopersicon esculentum Mill.) fruit quality (Mizrahi and Pasternak, 1985; Mizrahi et al., 1988; Orli, 1984; Pasternak et al., 1979; Plaut and Meiri, 1988; Shalhevet and Yaron, 1973) is increased under osmotic stress at the expense of fruit size and yield (Ehret and Ho, 1986).

The demand for new, exotic, healthy produce is the main reason for increasing interest in pepino dulce in the Western world. In addition to South America, the plant is being grown

Received for publication 25 Nov. 1991. Accepted for publication 29 July 1992. The cost of publishing this paper was defrayed in part by the payment of page charges. Under postal regulations, this paper therefore must be hereby marked advertisement solely to indicate this fact.

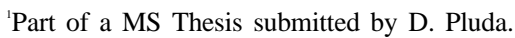

commercially in New Zealand, mainly for export to Japan, and markets are being developed in California, Europe, and Israel. Very little is known on suitable agrotechnique for this crop (Carrie1 et al., 1982; Dennis et al., 1981; Hermann, 1982), especially on the response of pepino dulce to $\mathrm{N}$ (Hermann, 1982) and salinity. We hereby report on the effect of those two factors on fruit quality characteristics.

\section{Materials and Methods}

Plant material. Seeds were received from G.J. Anderson (Storrs, Conn.) and from random collections in markets in South America, California, and New Zealand. Three individual plants, clone \#3 (selected by N. Kedar, Rehovot, Israel), and clones $\mathrm{B}$ and 113-12 were selected in Rehovot from 60 seedling populations. These clones excel in some agronomic and quality characteristics and share some common traits, such as erect growth habit, heavy fruit set, good color and size, and acceptable flavor.

Growing conditions and agotechnique. Shoot tops from healthy looking plants were rooted in a 1 vermiculite : 1 peat $(\mathrm{v} / \mathrm{v})$ mixture. Ten-day-old rooted cuttings were transplanted into a 1:1 (v/v) mixture of a sandy soil (96\% sand, $4 \%$ clay, $\mathrm{pH} 7.65)$ and perlite. They were grown in a temperature regulated glasshouse (15C minimum, 25C maximum) for 6 months. In the late spring, day temperature reached 30C. The bushy plants were thinned to two stems vertically supported by individual strings, and all lateral buds were removed. All trusses above the fourth or fifth inflorescence were pinched, for the first and second season, respectively. In the 1 st year, all sets were allowed to reach maturity. In the 2 nd year, only three fruits were allowed per cluster. Fruits were harvested daily when ripe, i.e., skin yellow and calyx folded upward.

The basal nutrient solution was according to Arnon (1938), but $\mathrm{N}$ was supplied as nitrates. The electrical conductivity of nutrient solutions was adjusted using $\mathrm{NaCl}$ and $\mathrm{CaCl}_{2}$ at 1:1 molar ratio. The composition of minerals used in the various treatments is specified in Table 1.

Individual pots were drip fertigated two to four times a day

$\overline{\text { Abbreviations: }}$ EC, electric conductivity; SSC, soluble solids concentration. 
Table 1. Mineral concentration in nutrient solutions for pepino dulce. All nutrient solutions contained $\mathrm{MgSO}_{4}, \mathrm{~K}_{2} \mathrm{SO}_{4}$, and phosphoric acid at 98,120 , and $98 \mathrm{mg} \cdot$ liter $^{-1}$, respectively.

\begin{tabular}{|c|c|c|c|c|c|c|}
\hline \multirow{2}{*}{\multicolumn{2}{|c|}{$\begin{array}{l}\text { Mineral } \\
\text { treatment }\end{array}$}} & \multicolumn{5}{|c|}{ Conc of Salts $\left(\mathrm{mg} \cdot\right.$ liter $\left.^{-1}\right)$} \\
\hline & & $\mathrm{KCl}$ & $\mathrm{KNO}_{3}$ & $\mathrm{CaCl}_{2}$ & $\mathrm{NaCl}$ & $\mathrm{Ca}\left(\mathrm{NO}_{3}\right)_{2}$ \\
\hline \multirow[t]{2}{*}{ N3 } & $\begin{array}{l}\mathrm{S}^{\mathrm{z}} \\
\mathrm{S} 3\end{array}$ & 74 & 303 & 192 & $-\overline{-150}$ & --- \\
\hline & $\begin{array}{l}33 \\
\text { S6 }\end{array}$ & $\begin{array}{l}74 \\
74\end{array}$ & 303 & & 750 & --- \\
\hline \multirow[t]{6}{*}{ N6 } & So & 14 & $\begin{array}{l}303 \\
404\end{array}$ & $\begin{array}{r}1692 \\
66\end{array}$ & 1500 & $\overline{164}$ \\
\hline & S3 & -- & 404 & 816 & $\overline{750}$ & $\begin{array}{l}164 \\
164\end{array}$ \\
\hline & S6 & $\cdots$ & 404 & 1566 & 1500 & 164 \\
\hline & So & $\cdots$ & 404 & -- & -.. & 656 \\
\hline & S3 & --- & 404 & 750 & 750 & 656 \\
\hline & S6 & --- & 404 & 1500 & 1500 & 656 \\
\hline
\end{tabular}

${ }^{z}$ The level of EC in the basal solution was $1.4 \mathrm{dS} \cdot \mathrm{m}^{-1}$. S0, S3, and by 0,3 , and $6 \mathrm{dS} \cdot \mathrm{m}^{-1}$, respectively.

(depending on moisture of the medium) at the rate of 2 liters $\cdot h^{-1}$. Fertigation was continued until one-third of the volume applied leached out. Growing media were washed every 2 weeks with excess nutrient solution so that the electrical conductivity (EC) of the leachate was very close to that of the treatment solutions, thus avoiding salt build-up in the pots.

Experiment design and mineral treatments. In 1989 clone \#3 was grown in a factorial design based on three nitrat: levels (3, 6, and 12 mmol-liter ${ }^{-1}$; N3, N6 and N12 respectively) and three chloride levels $\left(0,3\right.$, and $6 \mathrm{dS} \cdot \mathrm{m}^{-1} ; \mathrm{S} 0, \mathrm{~S} 3$, and $\mathrm{S} 6$, respectively). In 1990, all three clones were treated with $\mathrm{N}$ at N6 and N12 and with salt at S0 and S3. Plants were arranged in a randomized complete-block design with eight replicates

Fruit quality. Table ripe fruits were picked the day before evaluation. Excess fruits were picked and sorted so only those in good condition were used to measure quality. For each clone, at least eight fruits per replication were sliced and mixed for sensory analyses. Compositional and physical tests were performed on each fruit separately. The same physical and compositional tests were performed with fruits kept for 14 days at room temperature (range 18 to $25 \mathrm{C}$ ).

Firmness was determined by durometer (Chatillon \& Sons New York.) Thereafter, samples of 40 to $100 \mathrm{~g}$ of fresh pericarp were homogenized (Virtis blender, Precise, Racine Wis ) and 4-mI homogenates were sampled for ascorbic acid using the titration method (Williams, 1984). The remainder of each sample was filtered through double layer cheesecloth. The clear sera were analyzed as follows: SSC with bench top temperaturecontroIled refractometer (RFM-80, Bellingham \& Stanley Kent England); EC with conductivity meter (Radiometer, Copen hagen, Denmark); pH with pH-meter (Radiometer model 82). and titratable acidity (Gould, 1974). Total acidity was expressed as ppm citric acid (Gould, 1974), since over $90 \%$ of the pepino dulce fruit acidity is related to citric acid (Redgwell and Turner, 1986).

Organoleptic tests. The panel difference method was employed throughout for flavor evaluation. In the first season two tests were conducted using the ranking method (Gould 1974). The. first test was analyzed according to Durbin (Conover 1971), Using an incomplete-block design (Cochran and Cox , 1957), with 40 blocks of three sets of fruit samples (b). Twenty untrained tasters $(r)$ ranked the three fruit samples per block $(\mathrm{k})$ from the six $\mathrm{N}$ and salt treatments $(\mathrm{t})$. Using an index of $1(\mathrm{bad})$ to 3 (good), the tasters ranked two sets of three fruit slices according to general flavor, texture, and intensity of off-flavor.
The individual ranks $(\mathrm{Rj}, \mathrm{j}=$ treatment number) for each treatment were summed for each characteristic. The Durbin test statistic is defined as follows:

$$
T=\frac{12(t-1)}{\operatorname{rt}(k-1)(k+1)} \sum_{j=1}^{t}\left[R_{j}-\frac{r(k+1)}{2}\right]^{2}
$$

Significant differences between treatments were determined by comparing the Durbin statistic to the $x^{2}$ value at $t-1 \mathrm{df}$. Means were then compared using the multiple range test (Conover, 1971).

In a second evaluation, potential tasters were initially screened for flavor acuity. Chi-square tests for salt effects on flavor and off-flavor attributes were determined separately for N6 and N12 treatments.

Clones 3 and 112-13 were used in the 1990 organoleptic tests, employing an incomplete-block design (Cochran and Cox 1957), with the following input values $\mathrm{t}=4, \mathrm{k}=3, \mathrm{r}=18$ and $\mathrm{b}$ $=24$. Each group was ranked for flavor and bff flavors Statistical analysis was according to Durbin (Conover, 1971).

\section{Results}

Statistical analysis showed no interaction between the effect of $\mathrm{N}$ and salt. Hence, major effects of each of these factors were studied separately. In 1989, high salt concentration (S6) was toxic to plant and fruit development, and $\mathrm{N}$ at 3 meq.liter ${ }^{-1}$ $\mathrm{NO}_{3}$ was not adequate for proper plant development under our experimental conditions. Hence, in 1990, only S0 and S3 salt treatments and $\mathrm{N} 6$ and $\mathrm{N} 12 \mathrm{~N}$ levels were employed.

Fruit size. The main difference between the two experiments in crop management was the thinning of flowers in 1990 to three per cluster. The variation in fruit size observed in the 1989 season (unthinned) was markedly reduced in 1990 (Fig. 1) High $\mathrm{N}$ concentration (N12) increased fruit size only for clone 3 relative to N6. Addition of $\mathrm{NaCl}$ and $\mathrm{CaCl}_{2}$ to the nutrient solution resulted in a significant reduction of $15 \%, 21 \%$ and $26 \%$ in fruit size for clones 3, B, and 113-12 respectively as compared with the control. Fruit shape, however, was not affected by $\mathrm{N}$ or salt levels (data not shown).

Ascorbic acid content. The three genotypes varied considerably in ascorbic acid content (Table 2). Nitrogen level had no effect on this attribute of clones 3 and 113-12, but significantly lower concentrations were measured in clone B fruits at N12 as compared with those at N6. The levels of ascorbic acid were low when salt concentration were high, but only fruits of clone 113-12 were significantly affected by the S3 treatment.

Physical and chemical quality attributes of fresh fruit. Increasing the salt concentration resulted in significantly firmer fruit with higher levels of SSC as compared with the control in all three genotypes (Table 3). In the 1989 experiment (Table 4), acidity and EC of fruit sera were significantly increased and $\mathrm{pH}$ significantly decreased by salt and $\mathrm{N}$ treatments but remained unchanged in the second season (data not shown) The difference in EC between the extreme values was $\approx 1 \mathrm{dS} \cdot \mathrm{m}^{-1}$ equal to $\approx 10 \mathrm{mmol}$ charges/liter. At least half of that value can be attributed to an increase in fruit acidity, caused by the S6 salt treatments.

Effect of storage on quality attributes. Freshly harvested ripe fruits were stored on shelves in ambient conditions for 14 days There was a significant reduction in fresh fruit weights of $3 \%$, $4 \%$, and $5 \%$ for clones $113-12,3$, and $\mathrm{B}$, respectively but salt and $\mathrm{N}$ treatments had no effect. Fruit firmness declined during 

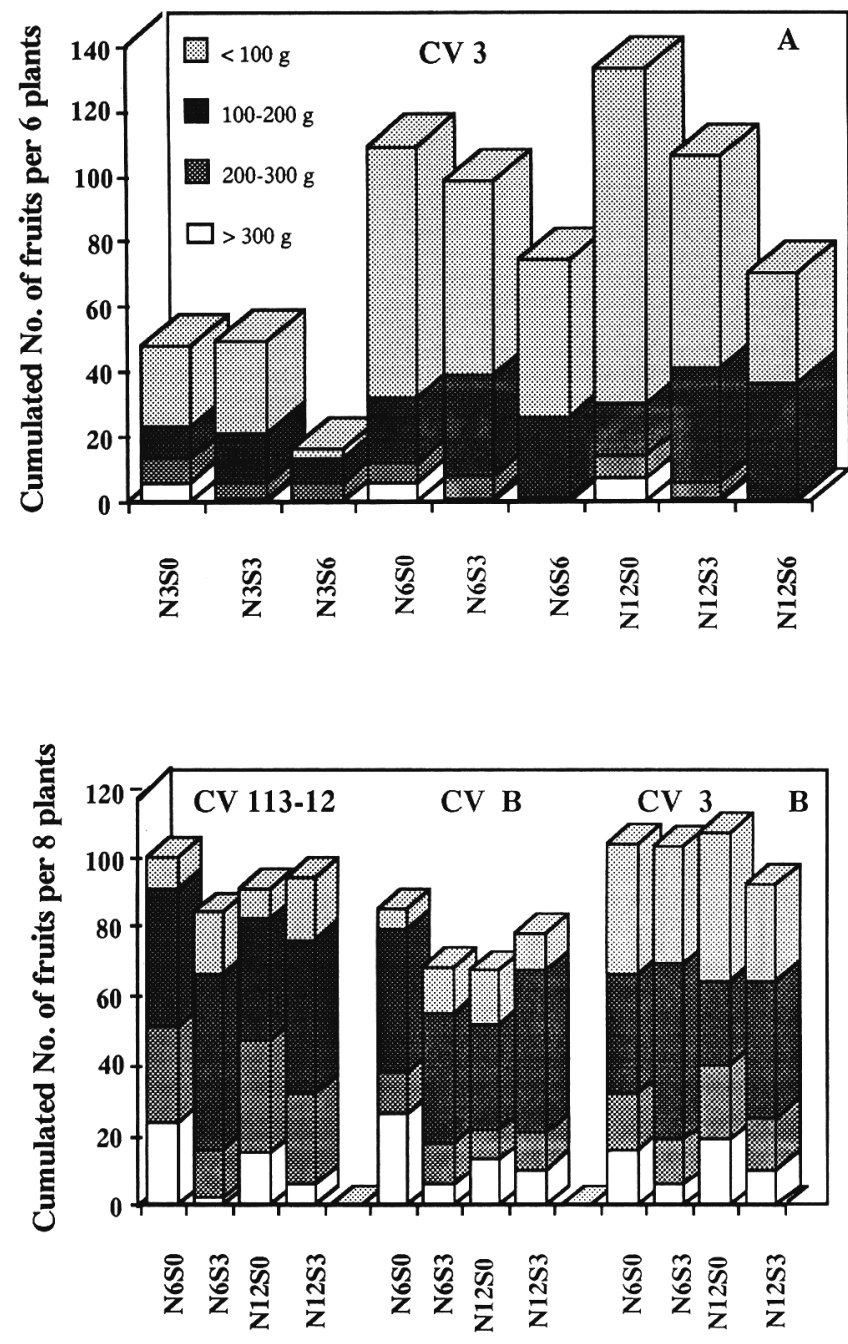

Nitrogen and salt levels (meq/L)

Fig. 1. Fruit distribution according to weight in the first (upper) and second (lower) experimental season.

Table 2. Effect of genotype, N, and salt on ascorbic acid content $(\mathrm{mg} / 100 \mathrm{~g}$ fresh weight) in pepino dulce fruit.

\begin{tabular}{lcccc}
\hline \hline & \multicolumn{4}{c}{ Ascorbic acid (mg/100 g fresh wt) } \\
\cline { 2 - 6 } $\begin{array}{l}\text { Mineral } \\
\text { treatment }\end{array}$ & \begin{tabular}{c} 
Clone 3 \\
\cline { 2 - 5 } \cline { 4 - 6 }
\end{tabular} & Clone 3 & Clone B & Clone 113-12 \\
\hline N3 & $38.3 \mathrm{a}$ & --- & -- & --- \\
N6 & $40.0 \mathrm{a}$ & $40.3 \mathrm{a}$ & $52.5 \mathrm{a}$ & $32.9 \mathrm{a}$ \\
N12 & $37.5 \mathrm{a}$ & $45.0 \mathrm{a}$ & $42.9 \mathrm{~b}$ & $31.5 \mathrm{a}$ \\
S0 & $46.3 \mathrm{a}$ & $45.2 \mathrm{a}$ & $50.5 \mathrm{a}$ & $35.5 \mathrm{a}$ \\
S3 & $38.8 \mathrm{a}$ & $39.8 \mathrm{a}$ & $45.3 \mathrm{a}$ & $28.9 \mathrm{~b}$ \\
S6 & $24.0 \mathrm{~b}$ & --- & --- & --
\end{tabular}

Data are means of eight to 16 fruit per replication per clone. Means are separated within columns for each mineral treatment by Tukey's LSD test $(P=0.05)$.

storage (Table 5) by $12 \%$ to $30 \%$. This decline depended on genotype and temperature prevailing during fruit growth and development, which were not the same during the 2 years. Ascorbic acid content increased in storage (Table 5) by $1 \%$ to $115 \%$, depending on cultivar, season, and salt concentration.
The effect of $\mathrm{N}$ or salt on the in storage variation in acidity and SSC was inconsistent (Table 5).

Sensory evaluations. Preliminary tests indicated the presence of off-flavor tastes in pepino fruit. Hence, panelists were asked to score separately for overall flavor and off-flavor intensities, and for texture. The pooled score $\left(\mathrm{R}_{\mathrm{i}}^{\prime}\right)$ for each character are presented in Table 6. Neither overall flavor nor off-flavor intensities were affected by $\mathrm{N}$ or chloride concentration in the nutrient solution, but textured scores were significantly higher in S6 treatments. The negative correlation coefficients between overall flavor and off-flavor intensities indicate that ranking by individual tasters was markedly affected by off-flavor intensity. Several tasters failed to sense off-flavors, but graded fruit flavor according to sourness, sweetness, and acceptable olfactory traits.

Taste panelists that disliked pepino dulce flavor did not participate in further organoleptic experiments. In the second evaluation, panelists were asked to rate each sample for both overall and off-flavor intensities (Table 7). At N6, but not at N12, an increase in salt concentration significantly improved fruit flavor. Correlation coefficients between the ratings of the two flavor components were not significant (data not shown).

In 1990, 18 tasters evaluated the effect of salt and $\mathrm{N}$ on the overall-and off-flavor intensities. An increase in both $\mathrm{N}$ and salt concentration improved overall flavor for clone 3 (from 24 to 48 for N6S0 and N12S3, respectively, maximum value $=54$ ), but not for clone 113-12. Off-flavor intensity was not affected by either of the treatments.

\section{Discussion}

The acceptability of a new product by consumers depends to a great extent on its quality. Visual attributes, such as size, shape, symmetry, color, olfactory, and some physical traits (e.g., firmness) determine whether or not a first purchase is made. Repeated purchase, however, depends on chemical attributes such as flavor and physical characters, such as texture.

Improvement in fruit quality can be achieved by both breeding and agrotechnique. The former is a long term project, whereas quality may be improved in a rather short period of time through appropriate crop management. Increasing total salinity of irrigation water is a common practice, although it may result in small fruits and reduced fresh yields (Ehret and Ho, 1986; Mizrahi, 1982).

Very little is known about quality attributes in pepino dulce and on their response to environment. To the best of our knowledge, there is no published report on consumer preferences of this fruit. Hence, the quality estimates are based on personal communications with randomly chosen consumers in Isreal, Europe, and the United States. In those countries, consumers prefer medium sized eliptoid-shaped pepino dulce fruit of 100 to $300 \mathrm{~g}$.

Our experience (unpublished) showed that low yields of diverse fruit sizes and shapes were obtained when growth of pepino dulce plants was not controlled. Staking had only minor effects. Trimming side shoots, however, markedly improved fruit set and yields, and fruit size was controlled to a great extent by thinning the number of sets per cluster (unpublished). As was the case for tomato (Ehret and Ho, 1986; Mizrahi, 1982), pepino dulce fruits from high saline nutrient solutions were significantly smaller (Fig. 1, Table 2), and yields were lower (unpublished) than the respective controls. Fruit size was less affected by mineral treatments than by thinning, suggesting that competition for photosynthates between fruits of each individual cluster was the primary factor 
Table 3. Effect of $\mathrm{N}$ and salt concentrations in the nutrient solution on firmness and SSC of fresh pepino dulce fruit.

\begin{tabular}{|c|c|c|c|c|c|c|c|c|}
\hline \multirow{3}{*}{$\begin{array}{l}\text { Mineral } \\
\text { treatment }\end{array}$} & \multirow{3}{*}{$\frac{1989}{\text { Clone } 3}$} & \multirow{2}{*}{\multicolumn{3}{|c|}{$\begin{array}{c}\text { Firmness }^{\mathbf{z}} \\
1990\end{array}$}} & \multicolumn{4}{|c|}{$\operatorname{SSC}(\%)$} \\
\hline & & & & & \multirow{2}{*}{$\frac{1989}{\text { Clone } 3}$} & \multicolumn{3}{|c|}{1990} \\
\hline & & Clone 3 & Clone B & Clone $131-12$ & & Clone 3 & Clone B & Clone $113-12$ \\
\hline N3 & $52 \mathrm{a}$ & -- & $\ldots$ & $\ldots$ & $10.9 \mathrm{~b}$ & $\cdots$ & --- & $-\cdots$ \\
\hline N6 & $50 \mathrm{a}$ & $46 \mathrm{a}$ & $45 \mathrm{a}$ & $53 \mathrm{a}$ & $11.8 \mathrm{~b}$ & $10.2 \mathrm{a}$ & $9.2 \mathrm{a}$ & $8.5 \mathrm{a}$ \\
\hline N12 & $53 \mathrm{a}$ & $45 \mathrm{a}$ & $43 \mathrm{a}$ & $50 \mathrm{a}$ & $13.4 \mathrm{a}$ & $10.4 \mathrm{a}$ & $9.6 \mathrm{a}$ & $8.8 \mathrm{a}$ \\
\hline So & $47 \mathrm{c}$ & $43 \mathrm{~b}$ & $43 \mathrm{~b}$ & $50 \mathrm{a}$ & $10.9 \mathrm{c}$ & $9.6 \mathrm{~b}$ & $8.6 \mathrm{~b}$ & $8.1 \mathrm{~b}$ \\
\hline S3 & $52 \mathrm{~b}$ & 48 a & $46 \mathrm{a}$ & 53 a & $12.3 \mathrm{~b}$ & $11.1 \mathrm{a}$ & $10.4 \mathrm{a}$ & $9.2 \mathrm{a}$ \\
\hline S6 & $57 \mathrm{a}$ & -- & $\ldots$ & $\cdots$ & $15.2 \mathrm{a}$ & $\cdots$ & --- & --- \\
\hline
\end{tabular}

${ }^{z}$ Firmness was estimated from three separate readings for each fruit of relative units using a Shore durometer.

Data are means of eight to 16 fruit per replication per clone. Means are separated within columns for each mineral treatment by Tukey's LSD test $(P=0.01)$.

Table 4. Effect of $\mathrm{N}$ and salt concentrations in the nutrient solution on electrical conductivity and acidity of sera of fresh clone \#3 pepino dulce fruit (1989 experiment).

\begin{tabular}{lccc}
\hline \hline $\begin{array}{l}\text { Mineral } \\
\text { treatment }\end{array}$ & $\begin{array}{c}\text { Titratable } \\
\text { acidity }^{2}(\mathrm{ppm})\end{array}$ & $\mathrm{pH}$ & $\begin{array}{c}\mathrm{EC} \\
\left(\mathrm{dS} \cdot \mathrm{m}^{-1}\right)\end{array}$ \\
\hline N3 & $650 \mathrm{c}$ & $5.66 \mathrm{a}$ & $3.32 \mathrm{c}$ \\
N6 & $850 \mathrm{~b}$ & $5.32 \mathrm{~b}$ & $3.57 \mathrm{~b}$ \\
N12 & $1120 \mathrm{a}$ & $5.18 \mathrm{c}$ & $3.88 \mathrm{a}$ \\
S0 & $780 \mathrm{~b}$ & $5.50 \mathrm{a}$ & $3.39 \mathrm{c}$ \\
S3 & $870 \mathrm{~b}$ & $5.35 \mathrm{~b}$ & $3.64 \mathrm{~b}$ \\
S6 & $1200 \mathrm{a}$ & $5.02 \mathrm{c}$ & $4.10 \mathrm{a}$ \\
\hline
\end{tabular}

${ }^{\mathrm{z}}$ As citric acid.

Data are means of eight to 16 fruit per replication. Means are separated within columns for each mineral treatment by Tukey's LSD test $(P=$ $0.01)$.

limiting the development of pepino dulce fruit. Reducing the competition for assimilates by trimming young heterotrophic side shoots increased yields. Limiting the number of sets per cluster increased fruit size and reduced variation in fruit size within and among clusters.

In tomatoes, ripening is affected by salinity. Ripe red tomatoes from plants treated with saline water have been reported to be firmer than controls (Mizrahi et al., 1988). However, such fruit have shown increased polygalacturonase (EC 3.2.1.15) activity (Mizrahi and Pasternak, 1985), accelerated softening, and reduced shelf life (Mizrahi, 1982). Pepino dulce fruit responded differently. Initial firmness was high in fruit from increased mineral concentration (Table 3), but softening of fruits from nutrient solution with low and high EC was equal (Table 5). Pepino dulce fruits, therefore, may be used as a comparative model for studies on ripening and senescence physiology and on the effect of salt stress on pectolytic enzymes and softening processes in ripening fruit.

Under normal conditions, dehydro-ascorbate is present at only $1 \%$ to $5 \%$ of the total ascorbic acid in tomatoes (Erdman and Klein, 1982). Hence, quantification of the reduced form provides a reliable estimate of vitamin $\mathrm{C}$ (henceforth ascorbate) (Erdman and Klein, 1982). Oxygen free radicals are generated in plant tissues under stress (Rabinowitch and Fridovich, 1983) and under saline conditions (Kalir and Poljakoff, 1981; Kayapova et al., 1983), and ascorbate participates in the chloroplastic defense mechanism against their damage. During these processes, ascorbate becomes oxygenated to the dehydro form (Halliwell, 1982; Halliwell and Gutteridge, 1989), which is then reduced by glutathione at the expense of $\mathrm{NAD}(\mathrm{P}) \mathrm{H}$ (Halliwell and Gut- teridge, 1989; Rabinowitch and Fridovich, 1983). Ascorbate concentration in pepino dulce was low in fruit from plants treated with saline solutions (Table 2), but poststorage levels of ascorbate were markedly higher in those and in high $\mathrm{N}$ fruits than in fruit from low EC solutions (Table 5). We suggest that under high EC conditions, much of the ascorbate was oxygenated. In storage, and especially under dim room illumination, much of the dehydro-ascorbate present in fruit from high EC treatment was reduced and, thus, became detectable.

SSC and acidity were key components in the overall flavor intensity in tomatoes (Stevens et al., 1977, 1979). In pepino dulce fruits, soluble sugars are the major component of dry matter (Redgewll and Turner, 1986; Schaffer et al., 1988), and $>90 \%$ of the acidity is related to citric acid (Redgewell and Turner, 1986). Hermann (1988) found no differences in dry matter content in pepino dulce fruit from plants treated with 2 , 5 , or $10 \mathrm{meq} \mathrm{N} / \mathrm{liter}$. Our results showed that much like in tomatoes (Mizrahi, 1982; Mizrahi and Pasternak, 1985), sugar content, total acidity, and EC were higher and $\mathrm{pH}$ was lower in fruit from salinized and high $\mathrm{N}$ plants as compared with control (Tables 4 and 5). Differences in genetic material used in Germany (Hermann, 1988) and in Isreal may in part explain the contradictory results. However, differences in growth conditions were probably the major reason for the differences in response to elevated $\mathrm{N}$ levels. In nontrimmed plants (Germany), additional $\mathrm{N}$ promoted vegetative development of main and side shoots. Hence, most photosynthates likely were channelled to young developing shoots rather than to fruits. When vegetative development is restricted (Israel), the fruits become the primary sink for sugars; thus, SSC and acid concentration increase in those organs.

Electrical conductivity of fruit sera was a general measure of all dissociated ions in the solution. Most positive charges were carried by inorganic cations, mainly $\mathrm{Ca}, \mathrm{Mg}, \mathrm{K}$, and $\mathrm{Na}$, and negative charges were mainly located on organic anions. Elevated concentration of nitrate in the external solution usually increases levels of citrate, malate, and oxalate, whereas increase in salt concentration increases chloride level in plant cells (Dijkshoorn et al., 1968). Those internal changes resulted in a concomitant increase in the serum EC (Table 4). The difference in EC value between $\mathrm{N} 3$ to $\mathrm{N} 12$ (Table 4) equals $0.56 \mathrm{ds} \cdot \mathrm{m} \cdot{ }^{-1}$. That value was equivalent to $\approx 5.6 \mathrm{meq} \cdot \mathrm{liter}^{-1}$. The total increase in salinity of the nutrient solution due to the $\mathrm{N}$ treatments was only $0.9 \mathrm{dS} \cdot \mathrm{m}^{-1}\left(12-3=9 \mathrm{mmol} \cdot \mathrm{liter}^{-1}\right)$, while that of the external salt treatments was $6 \mathrm{dSm}^{-1}(60 \mathrm{~mm})$. The maximum increase in serum EC in salt treatments was only 0.7 
Table 5. Quality attributes of pepino dulce fruit after 14 days storage at room temperature (mean $\pm \mathrm{SE}$ ) and change from value at harvest. ${ }^{z}$

\begin{tabular}{|c|c|c|c|c|c|c|c|c|c|}
\hline \multirow[b]{2}{*}{ Treatment } & \multicolumn{2}{|c|}{ Firmness } & \multicolumn{2}{|c|}{ Ascorbic acid } & \multicolumn{2}{|l|}{ Acidity } & \multicolumn{2}{|c|}{ SSC } & \multirow[b]{2}{*}{$\begin{array}{l}\text { Weight } \\
\text { loss (\%) }\end{array}$} \\
\hline & Mean & $\begin{array}{c}\text { Change } \\
(\%)\end{array}$ & Mean & $\begin{array}{c}\text { Change } \\
(\%)\end{array}$ & Mean & $\begin{array}{c}\text { Change } \\
(\%)\end{array}$ & Mean & $\begin{array}{c}\text { Change } \\
(\%)\end{array}$ & \\
\hline & \multicolumn{9}{|c|}{ Clone 3 (1989) } \\
\hline N6S0 & $34 \pm 2.0$ & -23 & $69 \pm 8.0$ & +62 & -.- & --- & $7.7 \pm 0.2$ & 0 & -- \\
\hline S3 & $40 \pm 0.8$ & -23 & $66 \pm 3.8$ & +46 & --- & --- & $9.5 \pm 0.3$ & -9 & --- \\
\hline S6 & $42 \pm 1.0$ & -25 & $57 \pm 3.4$ & +113 & --- & --- & $11.7 \pm 0.3$ & -6 & $--\cdot$ \\
\hline $\mathrm{N} 12 \mathrm{~S} 0$ & $38 \pm 0.7$ & -22 & $74 \pm 6.1$ & +43 & $-\cdots$ & --- & $9.2 \pm 0.3$ & -12 & $--\cdot$ \\
\hline S3 & $38 \pm 1.6$ & -30 & $72 \pm 6.0$ & +106 & -- & --- & $11.3 \pm 0.4$ & -5 & --- \\
\hline S6 & $45 \pm 1.2$ & -22 & $46 \pm 4.0$ & +115 & -- & --- & $13.3 \pm 0.4$ & -3 & -- \\
\hline N6S0 & $37 \pm 1.4$ & -16 & $58 \pm 5.1$ & +33 & $468 \pm 70$ & +22 & $9.6+0.5$ & +6 & $4.7 \pm 0.6$ \\
\hline S3 & $37 \pm 1.6$ & -23 & $59 \pm 3.2$ & +63 & $581 \pm 41$ & +35 & $11.3 \pm 0.5$ & -3 & $4.1 \pm 0.2$ \\
\hline $\mathrm{N} 12 \mathrm{~S} 0$ & $36 \pm 2.2$ & -14 & $51 \pm 5.9$ & +10 & $368 \pm 27$ & -3 & $9.1 \pm 0.3$ & -10 & $4.2 \pm 0.3$ \\
\hline S3 & $36 \pm 1.3$ & -22 & $58 \pm 4.3$ & +35 & $\begin{array}{r}392 \pm 33 \\
\text { Clone B }\end{array}$ & -3 & $11.1 \pm 0.4$ & +2 & $4.2 \pm 0.4$ \\
\hline N6S0 & $36 \pm 0.9$ & -15 & $62 \pm 3.1$ & +11 & $488 \pm 28$ & -4 & $8.6 \pm 0.3$ & +1 & $4.6 \pm 0.4$ \\
\hline S3 & \pm 0.8 & -17 & $57 \pm 4.0$ & +22 & $452 \pm 32$ & -26 & $9.5 \pm 0.4$ & -9 & $4.6 \pm 0.2$ \\
\hline $\mathrm{N} 12 \mathrm{~S} 0$ & $35 \pm 1.2$ & -15 & $59 \pm 5.3$ & +42 & $442 \pm 71$ & -18 & $9.5 \pm 0.3$ & +8 & $4.9 \pm 0.9$ \\
\hline S3 & $38 \pm 1.0$ & -14 & $52 \pm 2.7$ & +20 & $\begin{array}{l}410 \pm 21 \\
\text { Clone 113-12 }\end{array}$ & -1 & $9.5 \pm 0.3$ & -8 & $5.0 \pm 0.3$ \\
\hline N6S0 & $43 \pm 1.1$ & -18 & $37 \pm 2.6$ & +1 & $698 \pm 56$ & -4 & $7.7 \pm 0.1$ & -1 & $3.4 \pm 0.2$ \\
\hline S3 & $44 \pm 2.5$ & -17 & $32 \pm 5.4$ & +11 & $708 \pm 83$ & -9 & $8.8 \pm 0.1$ & -5 & $3.4 \pm 0.2$ \\
\hline $\mathrm{N} 12 \mathrm{~S} 0$ & $39 \pm 1.4$ & -20 & $34 \pm 5.0$ & +1 & $651 \pm 52$ & -2 & $8.0 \pm 0.1$ & -4 & $3.0 \pm 0.7$ \\
\hline S3 & $46 \pm 2.5$ & -12 & $32 \pm 3.7$ & +12 & $740 \pm 114$ & +19 & $8.9 \pm 0.1$ & -4 & $3.7 \pm 0.2$ \\
\hline
\end{tabular}

${ }^{2}$ Means are of eight replicates of each clone. Fruit firmness is given in relative values measured by Durometer, Ascorbic acid in $\mathrm{mg} / 100 \mathrm{~g}$ tissue; acidity is expressed as milligrams citric acid in liter fruit serum; SSC (\%) measured by refractometer. Dashes indicate no data taken.

Table 6. Effect of $\mathrm{N}$ and salt concentrations in the nutrient solution on overall intensity and off-flavor intensities and texture of pepino dulce fruit, and correlation between the two flavor components (1989).

\begin{tabular}{|c|c|c|c|c|}
\hline \multirow{2}{*}{$\begin{array}{l}\text { Mineral } \\
\text { treatment }\end{array}$} & \multirow{2}{*}{$\begin{array}{c}\text { Overall }^{z} \\
\text { flavor }\end{array}$} & Cor & & \multirow{2}{*}{$\begin{array}{l}\text { Correlation } \\
\text { coefficients }\end{array}$} \\
\hline & & \multicolumn{2}{|c|}{ Off-flavor texture } & \\
\hline N6S0 & 41 & 40 & $36 \mathrm{~b}$ & $-0.385^{\mathrm{NS}}$ \\
\hline S3 & 41 & 41 & $33 \mathrm{~b}$ & $-0.514^{*}$ \\
\hline S6 & 37 & 40 & $49 \mathrm{a}$ & $-0.567 * *$ \\
\hline $\mathrm{N} 12 \mathrm{~S} 0$ & 33 & 43 & $33 \mathrm{~b}$ & $-0.517^{*}$ \\
\hline S3 & 44 & 38 & $36 \mathrm{~b}$ & $-0.424^{\text {NS }}$ \\
\hline S6 & 45 & 40 & $54 \mathrm{a}$ & $-0.738 * *$ \\
\hline$T^{y}$ value & 7.9 & 0.76 & 26.3 & \\
\hline Significance & NS & NS & * & \\
\hline
\end{tabular}

${ }^{2}$ Rated on a 1 (bad) to 3 (good) scale. Each figure represents the sum of scores of 20 tasters. Maximum value $=60$.

y Durbin statistic.

*,**,Ns Significant at $P=0.05$ or 0.01 , or nonsignificant, respectively.

$\mathrm{dS} \cdot \mathrm{m}^{-1}$, very close to that of the $\mathrm{N}$ treatments. The efficiency of $\mathrm{N}$ in increasing internal salts dissociation thus was greater than that of $\mathrm{NaCl}$. The biological response of pepino dulce fruit in quality terms was much different from the chemical one. The organoleptic tests were very sensitive to salt treatments and less so to the increase in the $\mathrm{N}$ level. In tomatoes, sugars, and acids are the two major factors contributing to flavor intensity (DeBruyn et al., 1971; Stevens, 1970; Stevens et al., 1977; Stevens et al., 1979). Sugars contribute also to acceptable flavor of pepino dulce (El Zeftawi et al., 1977). High EC levels in the nutrient soltuion increased acidity of pepino dulce (Table 4). Salinity treatment increased SSC in tomatoes, melons, and pepino dulce fruits (Mizrahi and Pasternak, 1985; Table 4). Although concomitant improvement in flavor of tomatoes was also observed (Mizrahi et al., 1988), the sensory evaluations of melon (Mizrahi and Pasternak, 1985) and pepino dulce (Tables 6 and 7) were not necessarily related to off flavors. Hence, it was difficult to establish a linear realtionship between sugar to acid ratio and overall flavor. Our unpublished results showed that pepino dulce was sensitive to high temperatures. Midday temperatures were rather high in the last few weeks of the two experiments. Thus, we speculate that the increased temperatures during ripening

Table 7. Effect of $\mathrm{N}$ and salt concentrations in the nutrient solution on absolute frequencies of flavor ratings of pepino dulce clone 3 fruit (1989).

\begin{tabular}{|c|c|c|c|c|c|c|c|c|}
\hline \multirow{2}{*}{$\begin{array}{l}\text { Mineral } \\
\text { treatment }\end{array}$} & \multicolumn{4}{|c|}{ Overall flavor intensity } & \multicolumn{3}{|c|}{ Off-flavor intensity } & \multirow[b]{2}{*}{ Ranking ${ }^{z}$} \\
\hline & Good & Medium & $\mathrm{Bad}$ & Ranking ${ }^{2}$ & Weak & Medium & $\overline{\text { Strong }}$ & \\
\hline N6S0 & 0 & 13 & 7 & $\mathrm{~b}$ & 9 & 4 & 5 & NS \\
\hline S3 & 5 & 7 & 8 & $\mathrm{~b}$ & 3 & 9 & 6 & NS \\
\hline S6 & 15 & 0 & 5 & $\mathrm{a}$ & 6 & 5 & 7 & NS \\
\hline $\mathrm{N} 12 \mathrm{~S} 0$ & 7 & 8 & 6 & NS & 9 & 6 & 5 & NS \\
\hline S3 & 6 & 9 & 6 & NS & 8 & 4 & 8 & NS \\
\hline S6 & 6 & 4 & 9 & NS & 7 & 10 & 3 & NS \\
\hline
\end{tabular}

${ }^{2}$ Ranking distributions were compared using $\chi^{2}$ test $(P=0.05)$. 
adversely affected fruit flavor. However, more information is required before conclusions can be drawn.

Our findings (Table 5) confirm previous reports on the excellent keeping quality of pepino dulce (Hermann, 1988. Levano Herrera, 1977; Morley-Bunker, 1983), which, unlike tomatoes (Mizrahi et al., 1988), was not affected by salinity treatment. SSC and acidity were reduced with storage time (Table 5). In addition, there was a $3 \%$ to $5 \%$ weight loss and a slight firmness reduction, but those changes did not affect visual appearance and acceptance of the fruits by members of our taste panel.

Although enticing in shape and color, we believe that the flavor of the currently available pepino dulce fruit has not yet reached a level of quality that would attract European and Israeli consumers. Genetic variation within the species is large, and changes in nutrient composition and salinity have influenced fruit quality, especially flavor. Hence, it is quite likely that fruit quality may be improved by plant breeding and crop management. Large scale commercialization of the crop will require improvement in both aspects.

\section{Literature Cited}

Anderson, G.J. 1979. Systematic and evolutionary consideration of species of Solanum, section Basarthrum, p. 549-562. In: J.G. Hawkes, R.N. Lester and A.D. Skelding (eds.). The biology and taxonomy of the solanaceae. Linnean Soc. Symp. Ser., no. 7 (London).

Arnon, D.I. 1938. Microelements in culture-solution experiments with higher plants. Amer. J. Bot. 25:322-325.

Bernstein, L. 1964. Salt agriculture information. Bul. 283. U.S. Dept. Agr. Washington, D.C.

Carriel, R.A., A. Bravo, and A. Duimovic. 1982. Efectos de diferentes poblaciones de plantas sobre el rendimiento y caracteristicas de1 fruto de pepino dulce ( Solanum muricatum Ait.) Ciencia e Investigation Agraria, Univ. Catolica de Chile, Santiago de Chile. 9:215-219.

Cochran, W.G. and G.M. Cox. 1957. Incomplete block designs, p. 376-395. In: Experimental designs. 2nd ed. Wiley, New York.

Conover, W.J. 1971. Some methods based on ranks, p. 213-337. In: Practical nonparametric statistics. Wiley, New York.

Cossio, F. 1986. Il pepino o pera-melone, fruto esotico da sperimentare in orticoltura. Informatore Agrario 42(29):49-51.

DeBruyn, J.W., F. Garretsen, and L. Kooistra. 1971. Variation in taste and chemical composition of the tomato ( Lycopersicon esculentum Mill.). Euphytica 20:214-227.

Dennis, D.J., G.K. Burge, and R. Lill. 1981. Pepinos, cultural techniques. An introduction. Hort. Produce and Practice, N.Z. Min. Agr. Fish., no. 208, p. 2.

Dijkshoorn, W.J., D.J. Latwell, and C.T. De Wit. 1968. Temporal changes in carboxylate content of rye grass with stepwise change in nutrition. Plant Soil 29:369-390.

Ehret, D.L. and L.C. Ho. 1986. The effects of salinity on dry matter partitioning and fruit growth in tomatoes grown in nutrient film culture. J. Hort. Sci. 61:361-367.

El Zeftawi, B.M., L. Brohier, L. Delroy, F.H. Goubran, R. Holmes and B Scott. 1988. Some maturity indices for tamarillo and pepino fruits. J. Hort: Sci. 63:163-169.

Endt, D. 1983. Toma-a new pepino variety from Chile. The Orchardist of New Zealand 456(6):175.

Erdman, J.W. and B.P. Klein. 1982. Harvesting, processing and cooking influences on vitamin C in foods, p. 499-532. In: P.A. Seib and B.M. Tolbert (eds.) Ascorbic acid: Chemistry, metabolism and uses. Adv. Chem.

Gould, W.A. 1974. Tomato production, processing and quality evaluation. AVI Publ., Westport, Conn. p. 268-281.

Halliwell, B. 1982. Ascorbic acid and the illuminated chloroplast, p. 263-274. In: P.A. Seib and B.M. Tolbert (eds.). Ascorbic acid: Chemistry, metabolism and uses. Adv. Chem.

Halliwell, B. and J.M.C. Gutteridge (eds.) 1989. Free radicals in biology and medicine (2nd ed.), Clarendon Press, Oxford, England.

Heiser, C.B. 1964. Origin and variability of the pepino (Solanum muricatum): A preliminary report. Baileya 12:151-158.

Heiser, C.B. 1969. Pepino, p. 123-127. In: Nightshades, the paradoxical plants. Freeman and Co., San Francisco.
Hermann, M. 1988. Beiträge zur Ökologie der Frucht und Ertragsbildung von Solanum muricatum Ait. PhD Thesis. Institut für Nutzpflanzenforschung der Technischen Universität, Berlin.

Kalir, A. and A. Poljakoff-Mayber. 1981. Changes in activity of malate-dehydrogenase, catalase, peroxidose and superoxide dismutase in levels of $\mathrm{Hal}$ iminione partulacoides (L.) Allen exposed to high sodium chloride concentrations. Ann. Bot. 47:75-85.

Kameraz, A.J. 1958. Dynnaja gruscha. Solanum muricatum Ait., p. 386-393 In: D.D. Breschnew (ed.). Flora of cultivated plants, Moscow, vol. 20 (In Russian).

Kayapova; G.A., L.K. KIyshev, and N.M. Rakova. 1983. Role of superoxide dismutase in formation of nitrites in pea roots in the presence of salinization of the medium. Fiziologiya Rastenii 30:146-150.

Levano Herrera, B. 1977. Caracterización y comportamiento de post cosecha del pepino dulce ( Solanum muricatum Ait.). Thesis, Universidad de Chile, Santiago de Chile.

Levitt, J. 1980. Salt and ion stress. In: Responses of plants to environmental stress. Academic Press, New York. vol. II. p. 365-488.

Lizana, L.A. and B. Levano. 1977. Caracterizacion y comportamiento de postcosecha del pepino dulce ( Solanum muricatum Ait.) Trop. Reg. Amer. Soc. Hort. Sci. 21:11-15.

Maas, E.V. and R.H. Nieman. 1977. Crop salt tolerance-current assessment. J. Irr. Drainage Div. ASEC 103:115-134.

Mizrahi, Y. 1982. Effect of salinity on tomato fruit ripening. Plant Physiol. 69:966-970.

Mizrahi, Y. and D. Pasterak. 1985. Effect of salinity on quality of various agricultural crops. Plant \& Soil 89:301-307.

Mizrahi, Y., E. Taleisnik, V. Kagan-Zur, Y. Zohar, R. Offenbach E. Matan and R. Golan. 1988. A saline irrigation regime for improving tomato fruit quality without reducing yield. J. Amer. Soc. Hort. Sci. 113:202-205.

Morley-Bunker, M.J.S. 1983. A new commercial crop, the pepino ( Solanum muricatum Ait.) and suggestions for further development. Royal N.Z. Inst. Hort. Annu. J. Lincoln College, Canterbury 11:8-19.

Orli, H. 1984. Yield and quality control of tomatoes industry by $\mathrm{KCl}$ salinization. MS Thesis, submitted to the Faculty of Agriculture, The Hebrew Univ. of Jerusalem, 117 p. (Hebrew with English Abst.

Pasternak, D.M., M. Twersky, and Y. De Malach. 1979. Salt resistance in agricultural crops, p. 127-142. In: H. Mussel and R.C. Staples (eds.). Stress physiology in crop plants. Wiley, New York.

Plaut, Z. and A. Meiri. 1988. Effect of irrigation water salinity on quality and yield of greenhouse tomatoes in winter. Publ. Agr. Res. Organization, Bet Dagan, Israel. Ser. 90, no. 25 (in Hebrew).

Popenoe, W. 1924. Hunting new fruits in Ecuador. Natural History (New York), 24:455-466.

Rabinowitch, H.D. and I. Fridovich. 1983. Superoxide radicals superoxide dismutases and oxygen toxicity in plants. Photochem. Photobiol. 37:679690.

Redgwell, R.J. and N.A. Turner. 1986. Pepino ( Solanum muricatum) chemical compositions of ripe fruit. Sci. Food Agr. 37:1217-1222.

Rilska, A. and M. Borenstein. 1987. Pepino, a new crop in Israel. Publ. Agr Res. Organization, Ser. 5, no. 1906, p. 690-692 Bet Dagan, Israel (in Hebrew).

Schaffer, A.A., I. Rylski, and M. Fogelman. 1988. Carbohydrate content and sucrose metabolism in developing Solanum muricatum fruits. Phytochem. 28:737-739.

Shainberg, I. and J.D. Oster. 1978. Quality of irrigation water. Int. Irr. Info. Ctr. Bet Dagan, Israel, Publ. no. 2.

Shalhevet, J. and B. Yaron. 1973. Effect of soil and water salinity on tomato growth. Plant and Soil 39:285-292.

Shiota, H., H. Young, V. Paterson, and M. Irie. 1988. Volatile aroma constituents of pepino fruit. J. Sci. Food Agr. 43:343-354.

Stevens, M.A. 1970. Relationships between components contributing to quality variation among tomato lines. J. Amer. Soc. Hort. Sci. 97:70-73.

Stevens, M.A., A.A. Kader, and M. Albright. 1979. Potential for increasing tomato flavor via increased sugar and acid content. J. Amer. Soc. Hort. Sci. 104:40-42.

Stevens, M.A., A.A. Kader, M. Albright-Holton, and M. Algazi. 1977. Genotypic variation for flavor composition in fresh market tomatoes. J. Amer. Soc. Hort. Sci. 102:680-689.

Williams, S. 1984. Official methods of analysis of the associations of official analytical chemists. A.O.A.C., United States 14th ed. p. 844-845.

Yamaguchi, M. 1978. Solanaceous fruits. In: World vegetables: Principles, production and nutritive values. Univ. of California, Davis, p. 176-183. 